DIW BERLIN

Discussion

Papers

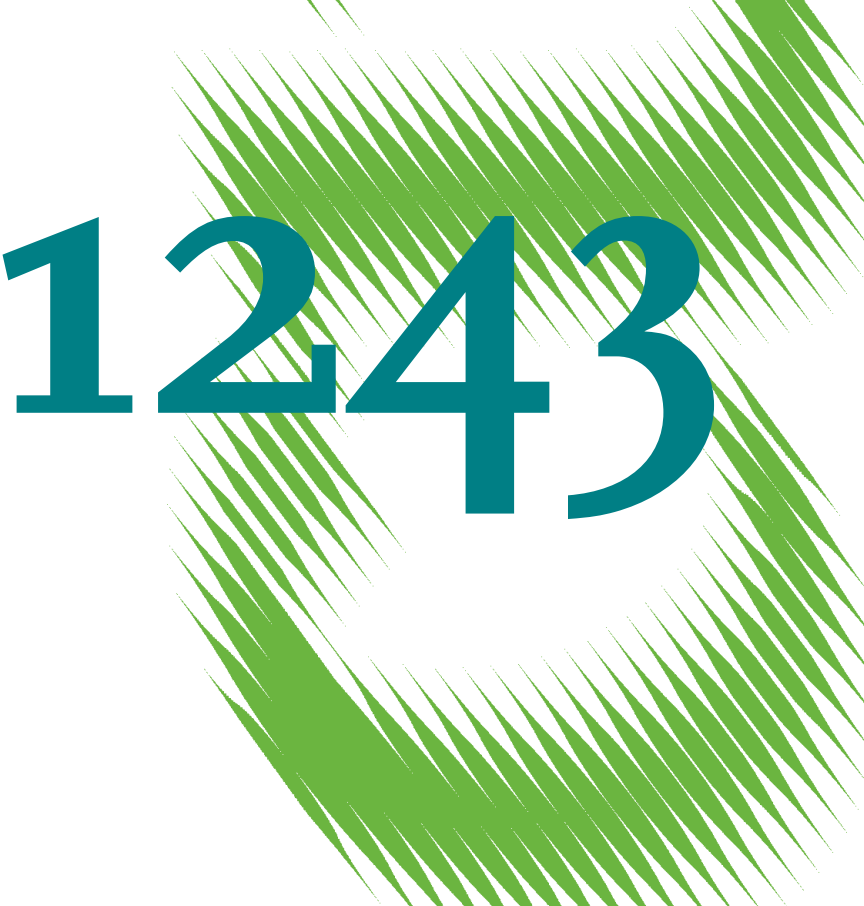

Age Effects in the Okun's Law within the Eurozone 
Opinions expressed in this paper are those of the author(s) and do not necessarily reflect views of the institute.

IMPRESSUM

(C) DIW Berlin, 2012

DIW Berlin

German Institute for Economic Research

Mohrenstr. 58

10117 Berlin

Tel. $+49(30) 89789-0$

Fax +49 (30) $89789-200$

http://www.diw.de

ISSN print edition $1433-0210$

ISSN electronic edition 1619-4535

Papers can be downloaded free of charge from the DIW Berlin website:

http://www.diw.de/discussionpapers

Discussion Papers of DIW Berlin are indexed in RePEc and SSRN:

http://ideas.repec.org/s/diw/diwwpp.html

http://www.ssrn.com/link/DIW-Berlin-German-Inst-Econ-Res.html 


\title{
Age effects in the Okun's law within the Eurozone
}

\author{
Oliver Hutengs ${ }^{a}$ and Georg Stadtmann ${ }^{b}$
}

August 2012

\begin{abstract}
We estimate Okun coefficients for five different age cohorts for several Eurozone countries. We find a stable pattern for all countries: The relationship between business-cycle fluctuations and the unemployment rate is the strongest for the youngest cohort and gets smaller for the elderly cohorts.
\end{abstract}

JEL classification: E24, F50, C23

Keywords: Okun's law, labor market, youth unemployment

a Oliver Hutengs, Wirtschaftswissenschaftliche Fakultaet, Europa-Universität Viadrina, Lehrstuhl für Volkswirtschaftslehre, insb. Wirtschaftstheorie (Makrooekonomik), Postfach 1786, Frankfurt (Oder), 15207, Telefon +49 (0)335 5534 2703, E-Mail: hutengs@europa-uni.de.

${ }^{b}$ Georg Stadtmann, Wirtschaftswissenschaftliche Fakultaet, Europa-Universität Viadrina, Lehrstuhl für Volkswirtschaftslehre, insb. Wirtschaftstheorie (Makrooekonomik), Postfach 1786, Frankfurt (Oder), 15207, Telefon +49 (0)335 5534 2700, E-Mail: stadtmann@europa-uni.de.

Georg Stadtmann serves also as a research professor at the Deutsches Institut für Wirtschaftsforschung e.V. (DIW Berlin), Mohrenstraße 58, 10117 Berlin, Germany. 



\section{Introduction}

The recent economic downturn affected the unemployment rates across European countries. However, the magnitude of this effect was not the same in all countries and within one individual country not evenly distributed across age cohorts. Youth unemployment rates in Spain and Greece increased substantially up to the level of $40 \%$ while the overall unemployment rates did not react by the same extent (see Fig. 1).

In order to study this pattern in unemployment in more detail, we estimate age specific Okun coefficients for five different age cohorts for several countries of the Eurozone. The results show that the coefficients are quite heterogeneous across countries. Nevertheless, we find a stable pattern that the relationship between business-cycle fluctuations and the unemployment rate is the strongest for the youngest members of the labor force.

The remainder of the paper is structured as follows: Section 2 discusses the literature and specifies the version of Okun's law examined within this study. Section 3 describes the data set and the empirical results. Section 4 summarizes the main findings.

\section{Literature review}

According to Okun (1962) business-cycle developments are negatively correlated with a change in the unemployment rate, that is positive business-cycle developments lead to a reduction in unemployment and vice versa. Much research has been conducted and almost all studies confirm this negative relationship (Knoester (1986), Paldam (1987), Kaufman (1988), Moosa (1997), Lee (2000), Freeman (2001), Silverstone and Harris (2001), Sögner and Stiassny (2002), Holmes and Silverstone (2006), Knotek (2007)). Therefore, Blinder (1997) calls it a core element of practical macroeconomic analysis we should all believe in. ${ }^{1}$

\footnotetext{
${ }^{1}$ Pierdzioch et al. (2011) analyze whether it is indeed the case that professional forecasters believe in this relationship. They use survey data for the G7 countries and report that professional economists' forecasts of changes in the unemployment rate and the growth rate of real output are consistent with Okun's law. See also Mitchell and Pearce (2010) in this context.
} 
Okun's law consists of many different versions, the original ones (i.e. gap and difference version) were proposed by Okun (1962). This paper focuses on the wellknown difference version which highlights that the change in unemployment rates is driven by the growth rate in real GDP. This is based on the assumption that an increase in output will need more factor input leading to a lower unemployment rate. The difference version, written as a linear regression model, is given by:

$$
u_{t}-u_{t-1}=\alpha+\beta \frac{G D P_{t}-G D P_{t-1}}{G D P_{t-1}}+\varepsilon_{t}
$$

where $u_{t}$ represents the unemployment rate in $t, G D P_{t}$ symbolizes the level of real GDP and $\varepsilon_{t}$ is the error term which satisfies the usual properties. The parameter $\beta$ is called the Okun's coefficient and is expected to have a negative sign.

\section{Dataset}

The dataset consists of annual real GDP data in constant prices of the year 2000 published in the Annual-Macro-Economic Database (AMECO) of the European Comission (2012). The unemployment rates for various age groups stem from (OECD, 2012) and are based on International Labour Organisation (ILO) standards. The observation period is 1983 to 2011. We include all countries of the European Monetary Union (EMU) that joined no later than 2001 with an exception of Luxembourg. ${ }^{2}$

- Insert Figure 1 about here -

Fig. 1 plots the unemployment rates of the youngest cohort as well as the overall unemployment rate for all countries examined. It reveals a substantial heterogeneity in the European labor markets. In Germany, the difference between the unemployment rate of the youngest cohort and the overall unemployment rate is

\footnotetext{
${ }^{2}$ The dataset for Austria is shorter, starting in 1994 as the unemployment rate for different age groups is not available at an earlier date. Countries that joined the EMU at a later date, i.e. mainly countries from eastern and south-eastern Europe, are excluded because of a lack of consistent data. Furthermore, Luxembourg is excluded as well because of its rather small economic weight.
} 
the lowest and the two unemployment rates show a very high positive correlation. Hence, we expect that the Okun coefficients for younger and older cohorts should not be very different. In Italy, the unemployment rate of the youngest cohort is fluctuating quite a bit over the business cycle, while the overall unemployment rate shows only little signs of variation. Spain has the highest difference between the two unemployment rates. Furthermore, the unemployment rates in Spain show the highest variation over the business cycle so that we expect that the Okun coefficient should take a relatively high (absolute) value.

We estimate equation (1) by OLS for each country and age cohort separately and display the regression results with respect to the absolute value of the $\beta$ coefficients in Figure 2. It shows the development of Okun's coefficient across different age cohorts for each country. The coefficient clearly diminishes with increasing age in all countries. The strongest decline in Okun's coefficient is observed from the 15-24 years cohort to the subsequent cohort (25-34 years). After the initial decline the coefficient decreases to a lesser extent across the subsequent age cohorts. This indicates that young people are indeed most vulnerable during economic downturns, but would also profit the most from an economic upswing.

- Insert Figure 2 about here -

Fig. 2 also confirms the hypotheses mentioned above: Germany shows a relatively small variation between the Okun coefficients across the different age cohorts. The Okun coefficients for Spain are the largest. Furthermore, the youngest cohort is exposed to a very high risk to loose their jobs during an economic downturn. Italy shows a very interesting pattern insofar as the Okun coefficients approach the value of zero for the older cohorts. This implies that these cohorts have managed to isolate themselves from business-cycle fluctuations.

\section{Summary}

Our study confirms previous research of, for example, Paldam (1987) or Lee (2000) that the size of the Okun coefficients differ quite substantially across countries. As a consequence, a symmetric GDP shock will lead to an asymmetric digestion and hence, an asymmetric effect on the governments' budgets. 
Nevertheless, we also find a stable pattern for all countries examined: The size of the $\hat{\beta}$-coefficients decays over the age cohorts so that the youngest cohort has the strongest exposure to the business cycle. As a policy conclusion, one might argue that huge gaps between unemployment rates across EMU countries might rise social or political tension between these countries. Since the Okun coefficients vary for different age cohorts a symmetric shock might also lead to inter-generational conflicts within individual countries. 
Figure 1. Youth and total unemployment rates for Eurozone countries
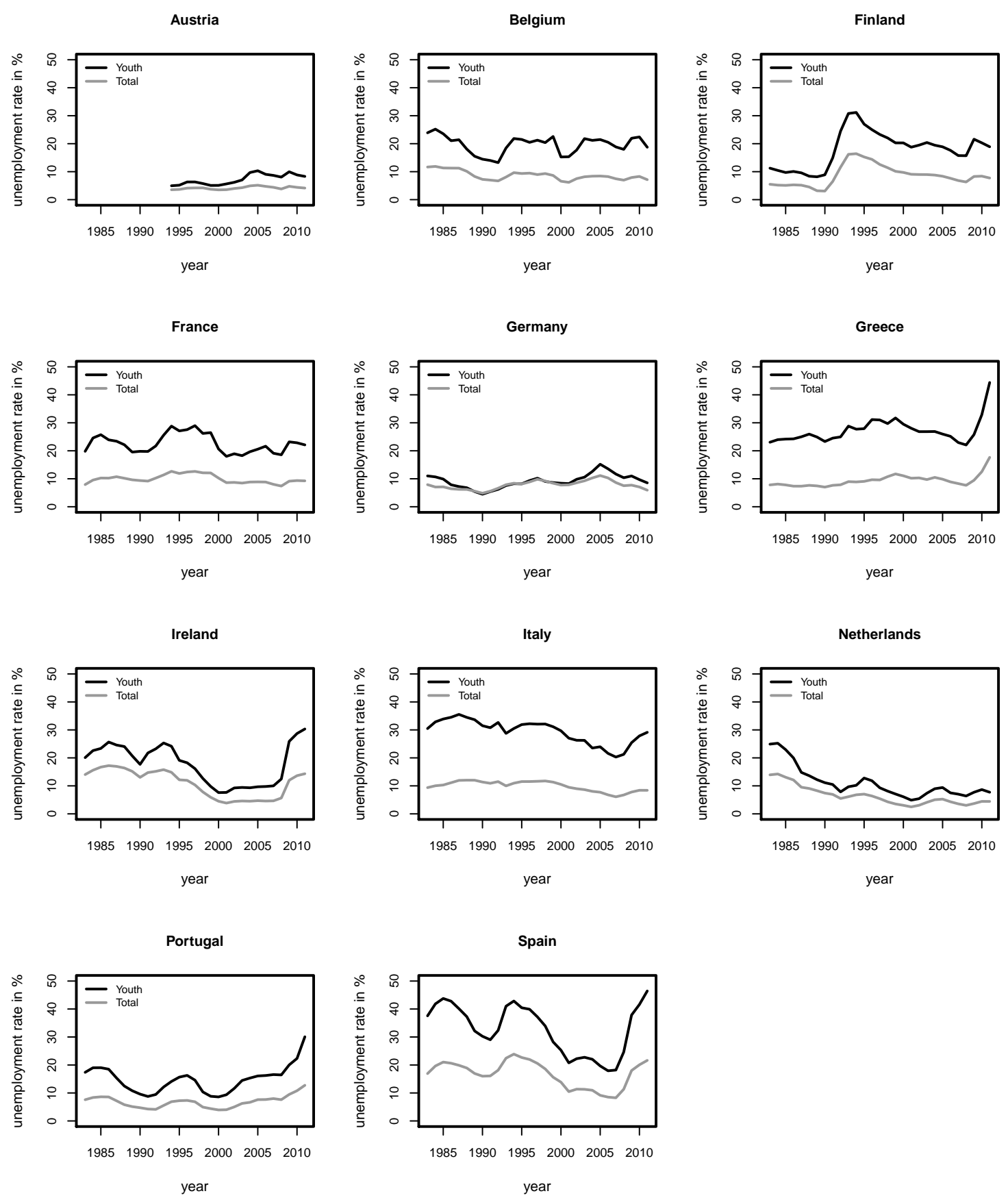
Figure 2. Okun's Coefficient over age groups

northern countries $1 / 2$

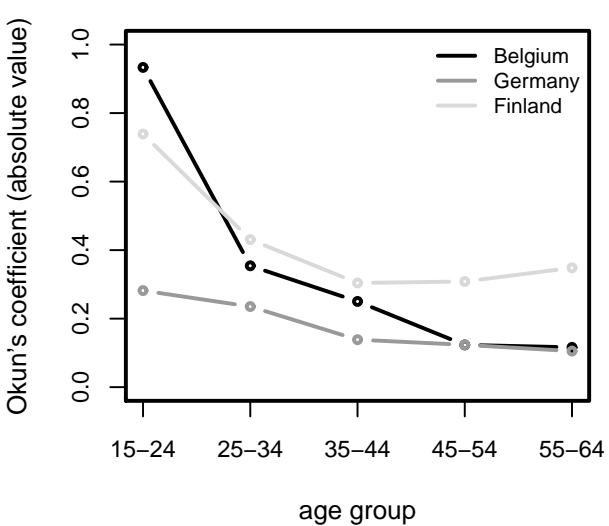

southern countries $1 / 2$

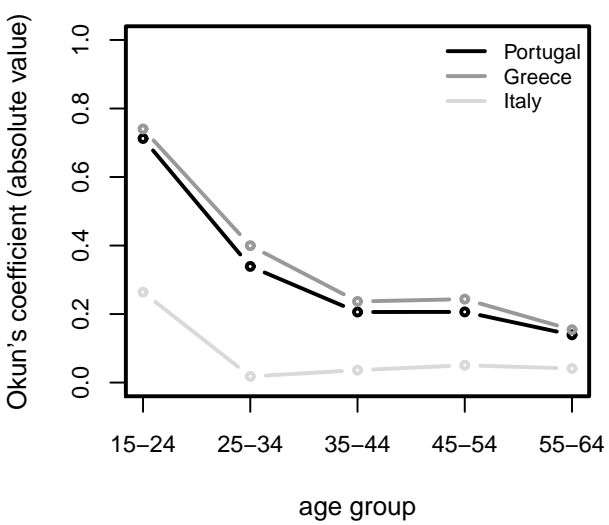

northern countries $2 / 2$

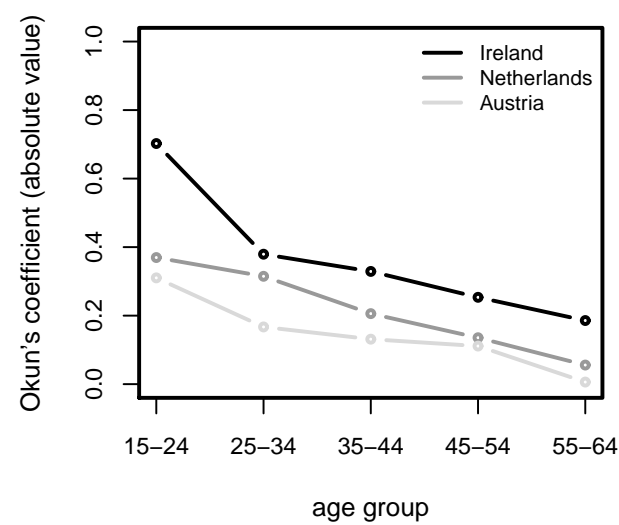

southern countries 2/2

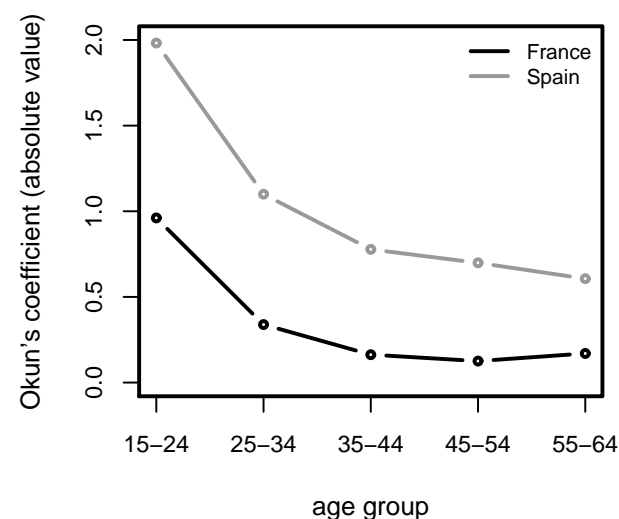

Note: The scale on the vertical axis of the lower right graph differs from the other ones. 


\section{References}

Blinder, Alan S. (1997), Is There a Core of Practical Macroeconomics That We Should All Believe?, The American Economic Review, 87(2), pp. 240-243.

European Comission (2012), AMECO Database.

URL http://ec.europa.eu/economy_finance/db_indicators/ameco/ index_en.htm

Freeman, Donald G. (2001), Panel Tests of Okun's Law for Ten Industrial Countries, Economic Inquiry, 39(4), pp. 511-523.

Holmes, Mark J. and Silverstone, Brian (2006), Okun's Law, Asymmetries and Jobless Recoveries in the United States: A Markov-Switching Approach, Economic Letters, 92(2), pp. 293-299.

Kaufman, Roger T. (1988), An international comparison of Okun's laws, Journal of Comparative Economics, 12(2), pp. 182-203.

Knoester, Anthonie (1986), Okun's Law Revisited, Weltwirtschaftliches Archiv, 122, pp. $657-666$.

Knotek, Edward S. (2007), How Useful is Okun's Law?, Economic Review, Federal Reserve Bank of Kansas City, Fourth Quarter, pp. 73-103.

Lee, Jim (2000), The Robustness of Okun's Law: Evidence from OECD Countries, Journal of Macroeconomics, 22(2), pp. 331-356.

Mitchell, Karlyn and Pearce, Douglas (2010), Do Wall Street economists believe in Okun's Law and the Taylor Rule?, Journal of Economics and Finance, 34(2), pp. 196-217.

Moosa, Imad A. (1997), A Cross-Country Comparison of Okun's Coefficient, Journal of Comparative Economics, 24(3), pp. 335-356.

OECD (2012), OECD.Stat.

URL http://stats.oecd.org/

Okun, Arthur M. (1962), Potential GNP: Its Measurement and Significance, in: The Battle Against Unemployment and Inflation (1982), edited by reprinted in Martin N. Baily and Arthur M. Okun.

Paldam, Martin (1987), How much does one percent of growth change the unemployment rate?: A study of 17 OECD countries, 1948-1985, European Economic Review, 31(1-2), pp. 306-313. 
Pierdzioch, Christian, Rülke, Jan-Christoph, and Stadtmann, Georg (2011), Do Professional Economists' Forecasts Reflect Okun's Law? Some Evidence for the G7 Countries, Applied Economics, 43(11), pp. 1365-1373.

Sögner, Leopold and Stiassny, Alfred (2002), An analysis on the structural stability of Okun's law-a cross-country study, Applied Economics, 34(14), pp. $1775-1787$.

Silverstone, Brian and Harris, Richard (2001), Testing for asymmetry in Okun's law: A cross-country comparison, Economics Bulletin, 5(2), pp. 1-13.

URL http://ideas.repec.org/a/ebl/ecbull/eb-01e00001.html 